\title{
Ethnography Within an Autobiographical Portrait: The Case of Camara Laye's the African Child
}

\author{
David Ako Odoi ${ }^{1 *}$, Ernest Kwesi Klu² \\ ${ }^{1}$ Language Centre, University of Ghana \\ ${ }^{2}$ University of Venda, South Africa
}

Corresponding Author: David Ako Odoi, E-mail: adodoi@ug.edu.gh

\begin{tabular}{|c|c|}
\hline ARTICLE INFO & ABSTRACT \\
\hline Article history & \multirow{9}{*}{$\begin{array}{l}\text { Africa as a continent has many ethnic groups. For most non-Africans, Africa is a homogenous } \\
\text { society and therefore all African societies and cultures are lumped together. There may be many } \\
\text { similarities between cultures. However, the subtleties in culture for each group are not obvious to } \\
\text { people outside Africa and most often they are ignored. Early novelists from Africa like Camara } \\
\text { Laye have sought to project their own unique stories and give an expose on what and why their } \\
\text { ethnic group puts up certain practices. In these stories however, the artist also invariably writes } \\
\text { the history or ethnography of the group. So, though Laye's work is regarded as a novel and in } \\
\text { most instances as an autobiography of childhood, the work has deep touches of ethnography and } \\
\text { therefore provides a bridge between these two spheres. It becomes therefore important to have } \\
\text { a close study of these two domains as shown in The African Child. This paper therefore aims at } \\
\text { investigating some ethnographic concerns of the Mandinka society and analyzes the purpose and } \\
\text { role of two prominent names used in the work. It is these apparently neglected part that aid in } \\
\text { projecting Laye's autobiography. }\end{array}$} \\
\hline Received: January 18, 2018 & \\
\hline Accepted: March 11, 2018 & \\
\hline Published: July 01, 2018 & \\
\hline Volume: 7 Issue: 4 & \\
\hline Advance access: May 2018 & \\
\hline Conflicts of interest: None & \\
\hline Funding: None & \\
\hline & \\
\hline
\end{tabular}

Key words: Ethnography, Totem, Autobiography, Culture, Mandinka, Mimesis, Sundiata Keita

\section{INTRODUCTION}

The autobiography, according to critics who favour it, is a chronicle of the life of a self who excavates his or her own past to discover what he was or often what he believes he was. Indeed, Lejeune (1982), Konuk Blasing (1977), Gusdorf (1956), Opoku-Agyeman (1989) and Shapiro (1965) have commented or argued extensively on the literary value of the autobiography. In spite of many criticisms leveled against the existence of the canon named the autobiography by equally articulate critics, the genre has survived and gained some stature in critical discourse. Beyond the standpoint that the autobiography is about the self in search for the self, one can identify other thematic concerns within the genre that are beyond the self being talked about but intrinsically linked to the same self. This is where the historical and cultural values of the society within the work of art becomes manifest.

History and culture of a people come up strongly together with the portraits of other characters who have relative dominance in the rhetoric of the text. In this vein, Camara Laye's work The African Child would be examined to show how it espouses history or general ethnography as well as portraits of credible characters; characters that are of importance in the history of the Mandinka people. This work will therefore investigate and discuss aspects of Mandinka culture in relationship to totems, the act of sowing, and circumcision. Be- sides, this paper will also take a look at two major characters because of how they affect Laye's life as well being epitomes of Mandinka culture.

\section{Totems}

Marriage among the Mandinka is exogamous. Therefore, Laye's patrilineal line (Camara) has a snake as its totem while the crocodile is the totem of Laye's mother's clan, the Dama clan. Nukunya (1992), explains a totem as an object, usually a plant or an animal, which is believed to have some ritual association with a group, so members of the group are supposed to treat it in a certain way. The phenomenon or association between man and his totem according to Weagel (2002) is discussed quite extensively in Carl Jung's Man and his Symbols (1964). The significance of this work stems from the fact that totems which are considered a part of primitive societies are as important as any other association or structure for the survival and growth of the society even in modern times. In a fictionalised autobiography, Laye has the leisure and license to indulge in artistic mimesis to underlie the artifice, hence the various aesthetic devices he uses that call attention to the work's fictiveness-- such as the centrality of totems-- are not only autobiographical but strategies to underline the fictional and ethnographic essence of the work. 
Consequently, Laye is able to show that those totems and the powers of magic are prominent in Africa and should not be considered to be illusionary. In other words, Laye's use of totems in his art is to underscore their importance and not to show that Africa is a primitive society. In fact, Collins and Makowsky (1998) in a study of Emile Durkheim's works note that, just as major world religions have ritual objects, aboriginal ethnic groups or tribes have the tribal totem which may be an animal that members of the tribal group are forbidden to kill or eat. Totems hold the tribe together and it is by sharing a common totem that members identify with each other. Also, the totem creates a social and moral order because it is forbidden to kill those who name themselves after the totem, which in this case, is one's tribesmen and women. Indeed for Collins and Makowsky (1998), tribal totems have been displaced by modern sacred objects like national flags, which represent a worship of the state. Also it is noteworthy that African national football teams especially take up names that are more or less the totems of their nations: 'The Indomitable Lions' of Cameroon, the 'Sparrow-Hawks' of Togo, the 'Teranga Lions' of Senegal, the 'Elephants' of Cote d'Ivoire, the 'Super Eagles' of Nigeria and the 'Black Stars' of Ghana to name a few. With the exception of Ghana, the names of the national teams enumerated are largely from animals. The portion on totems becomes important in Laye's autobiography since African ethnic groups are almost always guided by totems. The narrative space given to totems in the novel shows not only their factual significance but their relevance as aesthetic metaphors of the art. This therefore gives education to those who are not familiar with issues related to totems. It is noteworthy that Laye claims he sees all these issues of cultural significance from the eyes of a child.

\section{Harvest/Religion}

Religion also comes into focus when Laye narrates the events of harvest in Tindican, his mother's village. For an African, the land is so dear. The earth is regarded as a mother to whom her children come for sustenance. Indeed according to Weagel (2002) sowing of seeds is a male symbol which is expected to yield result from being in the earth which is the female and from this 'copulation', life is reborn several times. Weagel (2002) takes her cue from Jung's Dictionary of Symbolism where sowing in the earth is likened to a phallic sexual act. Weagel further supports this stance by referring to Simone de Beauvoir's The Second Sex (1989) where the earth is compared to a woman and the seeds sown within her burrows as representing the man. In The African Child, it can be observed that the harvest is a sacred and special occasion. Laye first uses a summary in the pace of narration when he indicates that:

It depended still more on the goodwill of the spirits of the soil, whose influence could be ignored. If their response was favourable, it only remained to beg of them, on the day before the harvest, to provide sunny skies and protection for the harvesters against the danger of snake bites. (p.45).

Laye is summative here because he does not know what goes into the inducement of the spirits for favour. It is also noteworthy that Laye professes to be a Muslim and so may not want to delve into issues like this which borders more on Traditional religion. Indeed some sacred and inexplicable rites are performed before the sickle cuts the first swathe of the rice. After these rites, the tom-tom is beaten before the harvest proper begins. Laye hides again in a summary by pleading ignorance:

As soon as the first sheaf had been cut, the tom-tom would sound, signaling the beginning of the harvest. Such is our custom. I could not have said then why his was done: why the signal was given only after the first swathe had been cut in each of the fields. I only know that such was the custom, and that was enough for me. Like all our customs, this one must have its own significance, which I could have easily found out from the elders of our village, who kept its secret meaning in the ancestral depths of heart and memory. (p.45)

Laye simply believes in the Malinke or Mandinka way of life. So, through a narration of this event, he is also able to create some mimesis or a slowdown scene to drum home this important socio-religious event as well as display rustic etiquette as shown or mimed on pages 48 to 50 of the novel. Laye in his depiction of his growth and development as a Malinke child does not put forward just his own tale but is also able to show the socio-religious traditions of his people as well as how these traditions mould his personality. Laye's work becomes rich in the use of the fictive tools to give variety to the narration as well as provide some ethnographic education on his society in general. An adult, Laye is defending a custom that transcends time. Besides it appears Laye is invoking a fiat as in 'This is it. I will not tell you further than this. This information is for insiders only'.

\section{Circumcision}

Another aspect of Mandinka culture which has ethnographic and religious significance is the initiation ceremony and circumcision of young men. This ceremony could be described as a socio-religious ceremony to bring into being a continuing cycle of Malinke life. The young men are more or less groomed to take over from the older ones who have replaced the dead or the ancestors. The young boys are collected from their homes and taken out into the bush for a whole night to meet the mythical Konden Diarra. The essence of the ceremony is to banish fear from the boys who will replace the patriarchs and thereby ensure the safety and continuance of the society. This rite is very important and to show its importance and the dread associated with it, Laye uses a slowdown scene:

'Well?' asked my father....

'Are you afraid?'

'A little,' I replied....

'What happens to you?' I asked

'Nothing you need to be afraid of, nothing you cannot overcome

by your will-power. Remember: you have to control your fear, you have to control yourself. Konden Diarra will not take you away; he will roar; but he won't do more than roar. You won't be frightened, now, will you?'

'I'll try not to be.'

'Even if you are frightened, do not show it' (p.80). 
This slowdown scene shows the extent of care a father has for his son and the importance of taking part in the ceremony. Beyond the care for a son, the Camaras belong to the best of the legendary Sundiata Keita's army. So, Laye's father ensures continuity in what is the Camara heritage. The honour and place of a Camara is demanded of young Laye both by his father and the general Mandinka society. The Mandinka are a conquering ethnic group and only the brave are needed. It becomes a disgrace if a Mandinka child is unable to overcome fear. The rite of circumcision, as noted earlier, is extremely important in the development of the male from the Mandinka society. Patrick R. McNaughton (1988), in his paper on Mande blacksmiths, explains:

For the Mande, circumcision constitutes a physical and psychic journey into adulthood. An uncircumcised male would simply not be considered an adult. In conversations with smiths and young men, I was repeatedly told that uncircumcised boys could not get married or have sexual intercourse, nor could they enter the important kòmò initiation association or accept the responsibilities families and communities give adults. Furthermore, they would be incapable of acquiring knowledge crucial to their spiritual and intellectual development. Finally, while they remain uncircumcised, no matter how old they are, they are conceived of as boys and are not held responsible for their acts; they can carry out the most annoying of pranks and behave very nearly as they please. They are considered more animal than human, in the sense that the social refinements that begin with circumcision have not yet begun to civilize them. After the blacksmith circumcises them, however, this period of grace comes to an abrupt end. Boys become men and are expected to act accordingly in all situations. (67).

So, much as The African Child is about the growth and development of Laye, the artist, he infuses within his personal history, some anthropological elements of his ethnic group couched in artistic leisureliness for his readers to have an insight of the workings of the ethnic group.

Initiation and circumcision ceremonies are not limited to Guinean societies but are very common among a lot of African societies. For instance, Kenyatta goes through lengths to explain this important socio-religious ceremony among the Kikuyu of Kenya in Facing Mount Kenya (1938). For Laye, circumcision is very important. The rite of circumcision is a sequel to the initiation ceremony. Circumcision is a sacred duty owed the ethnic group. Laye notes:

Our elders before us had paid for this thus; those who come after us would pay for it in their turn. Why should we be spared? Life itself would spring from the shedding of our blood. (p.93).

In the above quotation, Laye foregrounds the philosophy and religion of his ethnic group. It reveals the need for a complete cycle that ensures the continuity of the group. In a way, it is close to the sacrifice of the shedding of blood in the Christian religion where the shedding of Christ's blood is the ultimate sacrifice. The early pages of Chapter eight of Laye's are devoted to what is known as a 'descriptive pause' on the public part of the ceremony of circumcision. A descriptive pause is a time in the narration where the narration goes on but the story time is static. Laye meticulously describes why the ceremony of circumcision is important, why he and his age mates have to become 'born again' (p.93), the type of dress that is worn and the manner of dancing. Laye also explains why various interested parties offer gifts and why the gifts are necessary in such a ceremony.

Laye's description of the public part of the circumcision rite is long; thus, he intersperses this description with a metalepsis carved in simultaneous time to add variety to the narration:

'O thou'! he would say, 'hearken unto me. Thy family has always been loved by my family; thy grandfather is the friend of my father, thy father is my friend, and thou art the friend of my son. I come here this day that I might testify to these things in public. Let every man here know that we are friends, and that we shall remain ever so. And as a symbol of this lasting friendship, and in order to show my gratitude for the good will that thy father and thy grandfather have always shown to me and mine, I make thee this gift of an ox on the occasion of thy circumcision.' (p.96)

Simultaneous time is used by Laye because the above quotation is a blueprint that various people used before his time, during his own time and as at the present this is found to be still relevant. The rendition of this blueprint in what sounds like English from the King James Version of the Bible signifies that this is a custom practiced from in illo tempore and therefore sacred.

Laye for the first and only time within his work mentions the presence of a stepmother during the circumcision rites:

This was the time I saw my father's second wife make her appearance holding aloft an exercise book and a fountain-pen. I must confess that this gave me no pleasure at all and rather than encouraging me it embarrassed me, although I knew my second mother was merely observing an old custom, and so doing with the best will in the world, since the exercise- book and the fountain -pen were symbols of a profession which in her eyes, was superior to that of a farmer or a mechanic. (p.97)

Mentioning a stepmother once in the whole work is suggestive of the minor role. The role she plays in this particular instance is significant. Her display of the exercise book and pen, further accentuates the alienation of Laye from the traditional professions of being a farmer or blacksmith and invariably from a greater part of his culture. It is this sense of loss that Laye indicates that it gives him no pleasure at all. The circumcision rite plus the pen and exercise book are metonymic associations of great learning and great intellectual culture. So, though Laye's work focuses on the development of his individual personality, it also throws more light on the culture of the Mandinka and methods of cohesion in an African culture.

The paper so far has investigated and discussed some practices of the Mandinka society for their ethnographic significance. It will presently focus on some characters and the ethnographic associations of their activities and their names in the autobiography of Camara Laye. 


\section{CHARACTERS OF ETHNOGRAPHIC SIGNIGICANCE}

It has been noted strongly that The African Child is an autobiography written with novelistic tendencies. As an autobiography, it is told from the eyes of a child or what Laye believed he saw as a child. Names are innocently mentioned in Laye's story: names like Camara and Kouyate. However a close look into the origins and the stature of the names reveals significant ethnographic uses as this section of this work will show.

\section{The camaras}

One important person that comes up strongly in Laye's autobiography is his father who is not named. The question is why is he not clearly identified? His importance comes up not so much because he is Laye's father but the fact that among many things, he is a top blacksmith and jeweler in his community. Laye's father introduces the idea of religion and the supernatural to his son. Yet in another situation, Laye's father beats up the headmaster of the local school but instead of an expected reprimand from the Educational authorities or even the community, it is rather the assaulted headmaster who comes to apologize and is subsequently transferred. This unnamed man appears to live a charmed and untouchable life. For why all these events come into play about this unnamed man, one has to refer back not to the autobiography but to the history of the Mandinkas. In The Epic of Sundiata (1965), it is explained that Sundiata Keita, the Emperor of Mali, in the distribution of powers within his empire, told Kamandjan, King of Sibi:

'I give you back your kingdom, king of Sibi.... Today I ratify forever the alliance between the Kamaras of Sibi and the Keitas of Mali...the land of the Keitas shall be the land of the Kamaras, and the property of the Kamaras shall henceforth be the property of the Keitas.... May there never be a falsehood between a Kamara and a Keita, and may the Kamara's feel at home in the whole extent of my empire' (Niane, 1965, p.77)

The Camaras are by Mandinka culture, the 'owners of the land and their great ancestor Tabon Sibi Camara was a close associate of the legendary Sundiata Keita, the Emperor of the Mali Empire. In the sharing of privileges within the ancient Kingdom of Mali, the Camaras belong to the council of eminent persons called the Gbara. This Council is made up of 32 members from about 29 families. Within the subsections of this Council, the Camaras are represented in two of the four subsections named the Jon Tan Nor Woro who are descendants of the best soldiers of Sundiata and governors of the various provinces. The Camara's also belong to the Nyamakalla which by traditions deal with the occult and forge out products like jewelry art works and blacksmithing. (Djelli Mory Kouyate, personal communication, 14 $4^{\text {th }}$ July, 2013). By virtue of this relationship and the place in Mandinka history, Laye's father can never be reprimanded. When he and his assistants beat up a headmaster $t$ is the headmaster who was transferred and who also rendered an apology after being beaten.
In effect, the Camara clan is a highly favoured and respected clan and so a Camara serves as an archetype Mandinka and that may explain why Laye's father is unnamed yet is so powerful. So although Laye is telling his story from the point of view of a child, he is also revealing a very important structure in the Mandinka culture where the Camaras are almost equal to the Emperor of Mali. Indeed, it is the custom in Upper Guinea for any assembly to declare out of respect and for equity: "We are all Camaras" to show that everyone within the assembly is important (Djeli Mory Kouyate, personal communication, $14^{\text {th }}$ July 2013).

Again Niane (1965) informs us:

So Sundiata had divided the world at Kouroukan Fougan. He kept for his tribe the blessed country of Kita but the Kamaras inhabiting the region remained masters of the soil (p.78).

The Camaras are therefore untouchable and this high regard is what Laye captures for us without necessarily saying he belongs to a place of eminence. Respect for noble families therefore become a universal activity and not limited to some cultures.

\section{The kouyates}

The Kouyate name in The African Child starts with Laye's friend Kouyate who is said to 'have no stomach'. He is Laye's bosom friend till the end of the story. But of greater significance, the name Kouyate is made extra manifest in the father of young Kouyate, a revered old man in the village of Kouroussa. This Kouyate comes to the foreground when he invites Himourana, the bully to a meal in his house. When Himourana arrives, the younger Kouyate swears by "Allah" that Himourana collects his food and money from him. This encounter is so important that Laye captures it in a scenic presentation:

'My father,' he said, 'this is the boy who never stops beating me, and takes my food and my money!'

'Well, well,' said Kouyate's father, 'that's not a nice thing to say about him. Are you telling me the truth?'

'I swear by Allah!' said Kouyate.

'So it must be the truth,' said his father (p.72)

The question is why does the older Kouyate believe his son and does not question the supposed bully? Again we can understand this situation when we refer to the oral history of the Mandinka. Niane (1965) quoting Djeli Mamoudou Kouyate notes:

My word is pure and free of all untruth; it is the word of my father; it is the word of my father's father. I will give you my father's words just as I received them; royal griots do not know what lying is. When a quarrel breaks out between tribes it is we who settle the difference, for we are depositaries of oaths which the ancestors swore. (p.1)

Justice and fairness lie in the buxom of a Kouyate within Mandinka culture.

The senior Kouyate is again foregrounded during the Coba dance. Laye, the autobiographer, informs us that the 
senior Kouyate is the 'only' one who could lead this activity and again as an outsider from the Mandinka Culture one wonders why:

Kouyate's father, a venerable old man with white beard and white hair, thrust through the ranks and placed himself at our head: it was his privilege to show us how to dance the 'coba'...(p.100)

The Kouyates are also an embodiment of traditional history and practices. In Mandinka culture, the Kouyates are consulted on any issue related to 'what is acceptable'. They belong to the only Mandinka clan that can perform the roles of other clans. Kouyates are the law and interpreters of the law. Laye in his innocence 'merely narrates' that it is the elder Kouyate that leads the "Coba' but in reality he is revealing an important aspect of the Mandinka society. This is an aspect of continuity and social control.

\section{CONCLUSION}

This paper has basically argued that an autobiography can only be predominantly be about a single human person. However, there are other aspects of life like the ethnography of a people that becomes manifest in an autobiography. Camara Laye's The African Child gives this assertion very clear expression. The essay has trawled through the use and place of totems in the Mandinka society as the totems serve as unifiers. Also, issues related to circumcision and harvest rites among the Mandinkas receive critical attention and analysis. Circumcision is not only a ritual but an observation of an ancient act of drawing men into the army when the turn adults. Also great note are the rituals related to harvest. The rituals act as moderators and serve to instill etiquette. Finally, this paper notes the importance of two clans: the Camaras and Kouyates and explains why certain behaviours from these two clans are accepted without any questions. The clan system is a respectable vehicle for social cohesion. These aspects of the Mandinka society shows it as civilized and ccapable of ensuring social cohesion and continuity.

In all the paper has shown a link between the childhood autobiography of Camara Laye and some important aspects of Mandinka culture and practices.

\section{REFERENCES}

Collins, R. \& Makowsky, M. (1998). The discovery of society. Boston: McGraw Hill.

Finney, B. (1985). The inner I. London: Faber and Faber.

Genette, G. (1983). The narrative discourse: An essay on method (Jane E.Lewin, Trans.) Ithaca: Cornell University Press

Genova, J. (2004). Conflicted missionaries: Power and identity in French West Africa during the 1930's. In The Historian. www.encyclopedia.com/doc/1G1-135425230. html(HIGHBEAM ENCYCLOPEDIA)

Gusdorf, G. (1956). Conditions and limits of the Autobiography. In James Olney(ed., 1980) Essays critical and theoretical. Princeton University Press

Irele, A (2006). In search of Camara Laye. In Research in African Literatures Vol 37 Nol Bloomington: Indiana University Press.

Jay, P. (1984). Being in the text. Ithaca: Cornell University Press.

McNaughton, P. R.(1979). Bamana Blacksmiths. In African Arts. Vol.12. No.2 UCLA: James S. Coleman African Studies Centre.

Lejeune, P. (1975) The autobiographical pact. Paris

Niane, D.T.(1965). Sundiata: An epic of old Mali. London: Addison Wesley Longman Ltd.

Nukunya, G. K.(1992). Tradition and change in Ghana. Accra: Ghana Universities Press

Olney, J.(ed.) (1979) Essays critical and theoretical. Princeton University Press.

Opoku-Agyeman, K. (1989). African autobiography and literary theory. In Y. S. Boafo(ed.) Asemka. Cape Coast: Nsamankow Press

Shapiro,S. (1965). "The dark continent of Literature: Autobiography." In Comparative Literature Studies 5. (Pp 421-454)

Weagel, D.(2002). The Power, symbolism, and extension of the mother in 'L'enfant noir': A feminine portrait by a masculine author". In Rocky Mountain Review of Language and Literature. Vol. 56 No.1. pp.55-71

Wehrs, D. R. (2005) “Gendering the subject and engendering the self: Mande acculturation, Islamic piety and the forging of ethical identity in Camara Laye's L'enfant Noir'. In Modern Language Studies Vol.35 No.1 (pp.9-27) 